\title{
IEDITORIAL
}

\section{Current and new perspectives for interventional closure of ventricular septal defect}

\author{
Stephan Schubert \\ Center of Congenital Heart Disease, Heart and Diabetes Center Northrhine-Westfalia (HDZ-NRW), Ruhr-University of Bochum, Bad Oeynhausen, Germany
}

\section{RELATED ARTICLE by Cen et al,}

see p. 401
Correspondence to: Prof. Stephan Schubert, MD, Center of Congenital Heart Disease, Heart and Diabetes Center Northrhine-Westfalia (HDZ-NRW), Ruhr-University of Bochum, Georgstraße 11, 32545 Bad Oeynhausen, Germany, phone: +495731971380, email: sschubert@hdz-nrw.de Received: April 12, 2021. Accepted: April 13, 2021. Published online: April 23, 2021 Kardiol Pol. 2021; 79 (4): 378-379 doi:10.33963/KP.15950 Copyright by the Author(s), 2021
Ventricular septal defect (VSD) is the most common congenital heart defect with a prevalence of 5.27 diseased children per 1000 live births. ${ }^{1}$ In toddlers and small children with especially large defects, early treatment by surgical closure is the preferred and still frequent surgical procedure, whereas larger children or those with smaller defects may be alternatively treated with percutaneous device implantation. However, both methods carry a potential risk of, for example, complete atrioventricular block, with a risk rate of $0.1 \%$ to $6.8 \%$ after interventional VSD closure and less than $2 \%$ after surgical VSD closure. ${ }^{2,3}$ However, success and complication rates of interventional VSD closure depend on centers' experience and the device, which have been reported for various devices. ${ }^{4-7}$ With the increasing demand for more flexible devices and smaller profile, especially if compared with the Amplatzer perimembranous and muscular VSD occluder, more and more interventions have been performed with Amplatzer patent ductus arteriosus devices, such as Amplatzer Duct Occluder (ADO) I and II. 7,8 With these devices, nearly optimal short- and long-term clinical outcome data were achieved. ${ }^{4,7}$

In this issue of Kardiologia Polska (Kardiol Pol), Cen et $\mathrm{al}^{9}$ conducted a meta-analysis and systematic review on the worldwide experience with the use of the ADO II entitled "Efficacy and safety of the Amplatzer Duct Occluder II for ventricular septal defect closure: a meta-analysis." Although ADO I and II are still considered an "off-label" treatment, they have become available worldwide for successful patent ductus arteriosus and VSD closures in the last decades. Out of 150 potential publications (from 2012 to 2019), the authors selected 13 studies including $478 \mathrm{pa}$ tients who underwent interventional VSD closure, with an overall optimal success rate of $99 \%$.
Complication rates were low with $4 \%$ (95\% CI, $1 \%-7 \%$ ) for residual shunt, $0 \%$ for aortic valve regurgitation, $1 \%$ for tricuspid valve regurgitation, and $0 \%$ (95\% CI, 0\%-1\%) for complete atrioventricular block with the mean follow-up ranging from 6 to 40 months. Based on the meta-analysis, interventional VSD closure seems to have a high success rate and really low complication rate.

The new Lifetech Konar multifunctional occluder seems to combine or even optimize the requirements for a successful interventional VSD closure. It resembles a fusion of the ADO I and a disc from the ADO II, since it has a more conical shape on the left or high-pressure disk (similar to the ADO I), but still remains comparable to the ADO II with regard to the implantation cable and profile (5F-7F). Moreover, it received the CE mark already in 2018, and the first experiences have been reported. ${ }^{7,10}$ The ADO and Konar multifunctional occluders may hopefully imply a "renaissance" of interventional VSD closure.

\section{ARTICLE INFORMATION}

DISCLAIMER The opinions expressed by the author(s) are not necessarily those of the journal editors, Polish Cardiac Society, or publisher.

CONFLICT OF INTEREST Consultant \& Proctor for Abbott, CARAG, Edwards, Lifetech, Medtronic.

OPEN ACCESS This is an Open Access article distributed under the terms of the Creative Commons Attribution-NonCommercial-NoDerivatives 4.0 International License (CC BY-NC-ND 4.0), allowing third parties to download articles and share them with others, provided the original work is properly cited, not changed in any way, distributed under the same license, and used for noncommercial purposes only. For commercial use, please contact the journal office at kardiologiapolska@ptkardio.pl.

HOW TO CITE Schubert S. Current and new perspectives for interventional closure of ventricular septal defect. Kardiol Pol. 2021; 131: 378-379. doi:10.33963/ KP.15950

\section{REFERENCES}

1 Lindinger A, Schwedler G, Hense HW. Prevalence of congenital heart defects in newborns in Germany: results of the first registration year of the PAN Study (July 2006 to June 2007). Klin Padiatr. 2010. 222: 321-326. 
2 Ergün SG, Genç SB, Yildiz SB, et al. Risk factors for major adverse events after surgical closure of ventricular septal defect in patients less than 1 year of age: a single-center retrospective. Braz J Cardiovasc Surg. 2019. 34: 335-343.

3 Scully BB, Morales DL, Zafar F, et al. Current expectations for surgical repair of isolated ventricular septal defects. Ann Thorac Surg. 2010. 89: 544-549.

4 Bergmann M, Germann CP, Nordmeyer J, et al. Short- and long-term outcome after interventional VSD closure: a single-center experience in pediatric and adult patients. Pediatr Cardiol. 2021; 42: 78-88.

5 Haas NA, Kock L, Bertram H, et al. Interventional VSD-closure with the Nit-Occlud $®$ Lê VSD-Coil in 110 patients: early and midterm results of the EUREVECO-registry. Pediatr Cardiol. 2017; 38: 215-227.

6 Tzikas A, Ibrahim R, Velasco-Sanchez D, et al. Transcatheter closure of perimembranous ventricular septal defect with the Amplatzer ${ }^{\circledR}$ membranous VSD occluder 2: initial world experience and one-year follow-up. Catheter Cardiovasc Interv. 2014; 83: 571-580.

7 Udink Ten Cate FEA, Sobhy R, Kalantre A, et al. Off-label use of duct occluder devices to close hemodynamically significant perimembranous ventricular septal defects: a multicenter experience. Catheter Cardiovasc Interv. 2019; 93: 82-88.

8 Kanaan $\mathrm{M}$, Ewert $\mathrm{P}$, Berger $\mathrm{F}$, et al. Follow-up of patients with interventional closure of ventricular septal defects with Amplatzer Duct Occluder II. Pediatr Cardiol. 2015; 36: 379-385.

9 Cen H, Peng B, Li J, et al. Efficacy and safety of the Amplatzer Duct Occluder II for ventricular septal defect closure: a meta-analysis. Kardiol Pol. 2021; 79: 401-409.

10 Schubert S, Kelm M, Koneti NR, et al. First European experience of percutaneous closure of ventricular septal defects using a new CE-marked VSD occluder. EuroIntervention. 2019; 15: e242-e243. 